\title{
ANNOTATED CATALOGUE OF THE SPECIES OF PORITES AND SYNARFA IN THE UNITED STATES NATIONAL MUSEUM, WITH A DESCRIPTION OF A NEW SPECIES OF PORITES.
}

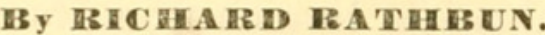

(With plates XV-XIX.)

This list comprises twenty-three species of Porites and three of Synarcea. One species of Porites from the Brazilian coast is described as new, and notes are given on Porites clavaria, furcata, astraoides, and solida. From the collection of the United States Exploring Expedition, Professor Dana described eighteen new species of Porites, including variety mucronata of $P$. nigrescens, and $P$. contigua Dana (won Madrepora contigua Esper), which have since been recognized as distinct species. Of these species, fourteen are now referred to the genus Porites and four to the genus Synarce of Verrill. Types of all of Dana's species, excepting Porites levis and Porites (Synaraa) informis, are now in the collection of the National Museum, which also contains the type specimen of P.tenuis Verrill, obtained by the North Pacific Exploring Expedition. A large and fine series of the three common Antillean species have recently been added to the collection from Southern Florida, and two of the same species are well represented from Bermuda.

The numbers in parentheses refer to the record books of the National Museum.

\section{Genus PORITES Lamarek.}

1. Porites astræoides Lamarck,

Hist. des Anim. sans Vert., ii, p. 269, 1816.-Agassiz, Mem. Mus. Comp. Zool., vii, No. 1, pl. 16, figs. 1-12, 1880.

Bermuda; Bermuda Cent. Commissioners, 1876 (3189); G. Brown Goode, 1876, in exchange with Wesleyan University (15846); G. W. Hawes, 1882 (15519).

Nassau, Bahama Islands; U. S. Fish Commission str. Albatross, 1886 (15514).

Kèy West, Fla.; E. Palmer, 1884 (15517, 15518); H. Hemphill, 1885 (8897).

Eastern Dry Rocks, near Key West, Fla.; E. Palmer, 1884 (15520).

Dry Tortugas, Fla.; Capt. D. P. Woodbury, U. S. A. (1640); E. Palmer, 1884 (15521).

Old Providence Island, Caribbean Sea; U. S. Fish Comm. str. Albatross, 1884 (15515).

Curaçao Island, Caribbean Sea ; U. S. Fish Comm. str. Albatross, 1884 (7236).

The Bermuda specimens agree with those from Florida in their mode of growth, but differ from them in generally having rather larger cells with the septa wider in the upper part, making the cells appear less deeply excavate, though they may be equally deep in the center. The specimens vary considerably in this particular, and in some cases the cells are comparatively shallow throughout. This species is described by Mr. Goode as one of the most common in the shallow waters about the Bermucia reefs, ranging from low-tide level to depths of 2 and 3 
fathoms. It is not recorded from Bermuda by Mr. Quelch in his report on the Challenger reef-corals.

2. Porites Branneri, new species.

(Plate XIX, fig. 2.)

Corallum small, either incrusting, more or less convex, or subglobular in shape, generally irregular, but with an even surface, and withont defined protuberances or branches of any kind. The cells are very small, shallow to moderately deep, without columella but with prominent pali. The corallum is usually attached by the entire base, and may be slightly constricted or expanded at the margins, but the latter are sometimes free in places for a slight width, the under surface where exposed being provided with a thick epitheca, which is strongly wrinkled concentrically. None of the specimens are relatively thin, though some are nearly flat on top. One of the largest of the incrusting forms measures about 50 by 35 by $7.5^{\mathrm{mm}}$ thick in the middle, while one of sub. globular shape is about $65^{\mathrm{mm}}$ in diameter.

The structure is everywhere very loose and open, especially near the surface, the processes sometimes becoming more thickened below, but always with large perforations. The cells are small, remarkably uniform in size in each specimen, and not varying much in the entire series examined; .75 to $1^{\mathrm{mm}}$ in diameter, polygonal, separated by thin walls, and with moderately thick septa which vary more or less in the different specimens. In some cases the cells are entirely superficial near the margins, but usually they are moderately deep and of the same diameter at the base as at the top. The processes entering into their structure are generally more or less strongly echinulate, being armed with very small, acute spinules, giving the interior a much roughened appearance. Columella absent, bottom of cell usually perforated, but sometimes more or less filled in. Pali 4 to 6 , generally 5, in number, regularly placed, very prominent, echinulate, varying with the thickness of the septa from slender to moderately stout; in the deeper cells they extend about half way from the bottom to the top, but in the shallower ones they often reach to the surface. The septa are twelve in number, and vary in thickness and width; they are unequal in width in the same cell and generally extend from one-half to twothirds the distance from the wall to the pali, but are often much narrower. Above the base each consists of one to three disconnected processes, more or less resembling the pali in appearance, and projecting inward from a narrow vertical ridge upon the wall. In the bottom of the cell, 8 to 10 of the septa meet in the middle, generally first uniting in pairs, and afterwards becoming more or less connected together by processes which inclose the small central cavity. The upper edges of the walls are serrate, caused by the upward extension of the septa in the form of irregular processes, which are generally echinulate, though sometimes nearly smooth. 
This small species is very distinct from Porites solida Verrill, the only other member of the genus yet recorded from the Brazilian coast, and $I$ have also been unable to unite it with any of the species described by Duchassaing and Michelotti from the Caribbean Sea. Its principal characteristics are the mode of growth, the generally smooth surface, small crowded cells, separated by thin but distinct walls, the lack of columella, conspicuous pali, and fine echinulation of all the processes. The amount of variation is not great, though in some specimens the septa and walls are thicker than in others, and in such cases the echinulation is generally less marked. Thirty-two specimens have been examined by the writer from the following localities: Parahyba do Norte, near the city of Pernambuco, and the Bay of Bahia. The species is represented in the National Museum collection as follows:

Parahyba do Norte, Brazil ; J. C. Branner, 1876, type (10961).

Candeias Reef, Pernambuco, Brazil ; C. F. Hartt, 1875, types (10962).

3. Porites clavaria Lamarek,

Hist. des Anim. sans Vert., ii, p. 269, 1816.-Agassiz, Mem. Mus. Comp. Zool., vii, No. 1, pl. xii, figs. 4-6, 1880.

(Plate XVI; pl. XVII, fig. 2 ; pl. XVIII; pl. XIX, fig. 1.)

Bermuda; Bermuda Cent. Commissioners, 1876 (3160); G. Brown Goode. 1876, in exchange with Wesleyan University (15867); G. W. Hawes, 1882 (15868).

Bahamas: Nassau, New Providence; U.S. Fish Comm. str. Albatross, 1886 (15870). Florida :

(?)* Cæsar's Creek, 17 miles south of Cape Florida; E. Palmer, 1884 (15872). Rodriguez Creek, 40 miles south of Cape Florida ; E. Palmer, 1884 (15863).

Stock Island and Salt Pond Key, about 6 miles NE. of Key West; E. Palmer, $1884(15864,15865)$.

Eastern Dry Rocks, 9 miles SW. of Key West; E. Palmer, 1884 (15866).

Tortugas; Capt. D. P. Woodbury, U. S. A. (1638) ; E. Palmer, 1884 (1585915862).

West Indies ; J. D. Dana (706).

The branching Porites of the Antillean region are represented in the National Museum by a very large series of specimens, coming mainly from Southern Florida, the Tortugas, and Bermuda. The collection from the Florida reefs, including the Tortugas, comprises several hundred specimens in fine condition, the most of which have been recently obtained expressly for this Musenm. They were collected at several different localities between Cape Florida, at the northern extremity of the reefs, and the Tortugas, at the southwestern extremity. At each locality large numbers of specimens were secured, and the collection as a whole affords an excellent opportunity to study the numerous variations in growth and structure, which render it so difficult to separate the species.

As stated by Pourtales, the structure of the cell alone is not sufficient to characterize the two branching species now recognized from

${ }^{*}$ A mark of interrogation before the name of a locality indicates that the identity of the specimens from there is somewhat uncertain. 
Florida; but the same is almost equally true with respect to the mode of growth, although clavaria is usually a much stouter form than furcata. In both species the columelia may be present or lacking even in the same specimen, but, as a rule, the center of the cell is seldom deeply perforated, and the free portion of the columella is much more slender and less conspicuous than the pali, which are generally well developed. Constant reliance cannot be placed upon the relative compactness of the texture, either internally or externally, but it is generally somewhat looser in furcata, the cells rather smaller, irregular, polygonal, separated by thin walls; while in clavaria the walls are often much thickened, porous, the septa sometimes, but not always, better developed, the excavated portion of the cell almost always circular in outline and regular. The cells may be superficial to moderately deep in both species, but become most excavated at times in clavaria ; the echinulation varies similarly in both, but the processes are very rarely nearly smooth in either, and when so are much twisted and very irregular. The figures of the cells of furcata and clavaria given in "The Memoirs of the Museum of Comparative Zoology," vol. vii, 1880, pl. xii, fig. 5, pl. xvi, fig. 14, might serve indifferently for either species, but those on pl. xii, fig. 5, labeled clavaria, are of rare occurrence in our collection.

In classifying the collection in the National Museum, the writer has followed as closely as possible the views of Dana, Verrill, an d Pourtales, relying for his data upon specimens in the old collection labeled by Dana and Verrill, and upon the few brief diagnoses that have been published. There is no difficulty in assigning most of the specimens to one or other of the two species, which appear rery distinct in what may be called their typical forms, but there exist a large number of interm ediate varieties the exact position of which cannot be determined, and which render the specific value of the two forms somewhat doubtful. The depth at which they grow and the nature of their surroundings undoubtedly have much to do with the character of their growth, but many of the variations cannot be explained by such means. It is to be regretted that fuller notes are not made by collectors in the field upon the conditions attending the growth of such forms as these, for they would probably serve to show relationships which might not otherwise be suspected. Fortunately, in the last and largest collection received from Florida all the specimens from each locality have been kept together, and it is shown that each spot hasits peculiar variety or varieties, differing more or less from those of all the others.

In the specimens referred to furcata, the tendency is to form small, more or less dense, clumps, composed of rather slender, rapidly dividing branches, with relatively small, erowded, polygonal and often very irregular cells, separated by thin walls, and either superficial or moderately excavated. In clavaria, which is more varied in growth, the branches, on the contrary, are generally stout, dividing much less rapidly and forming open clumps or very short, rapidly tapering and 
twisted, more or less proliferous trunks, arising from an almost solid base; in some cases the clumps are dense, but the branches retain the same character as in the open growths. The cells are relatively large, usually circular and regular in outline, with thicker walls than in furcata, and may be either very shallow or deeply excavate. The specimens that are difficult to classify are mostly intermediate both in mode of growth and in the character of the cells, but very exceptional varieties oceur. Large cells, containing from eighteen to twenty-four septa, occur frequently in both species, but have been noticed most often in clavaria. The majority of the specimens of the latter species examined have at least one of these enlarged cells, and some have several, but they are never numerous on any one specimen. They are as common in the Bermuda specimens as in those from Florida, and are apparently no more abundant in the few specimens of $P$. porosa which this Museum has received from Lower California.

The following notes upon the specimens of clavaria in the National Museum may be of service to others in identifying that species. The varieties of $P$. furcata are described further on. The figures given on plates XV-XVIII, and figure 1 of plate XIX, are intended to illustrate the principal variations in growth of these two species as represented in the Museum collection. The process by which they have been engraved does not permit of showing the details of structure on so small a seale, but an attempt has been made to imitate the general appearance of the surface. The drawings are by Mr. A. H. Baldwin.

Near Salt Pond Key, 6 miles northeast of Key West (Pl. XVI, figs. 1 and 2).-One of the finest series of specimens of clavaria was obtained near Salt Pond Key and between there and Stock Island, where the surroundings are evidently very favorable to the growth of this species. They form mostly very open clumps of few, widely divergent branches, starting from a single stem, and varying in diameter from 16 to $35^{\mathrm{mm}}$. Branching takes place at intervals of 20 to $70^{\mathrm{mm}}$, and is generally simple. The branches are mostly circular in section, sometimes more or less compressed, slightly swollen or constricted in places, but for the most part quite regular; straight or slightly sinuose in the intervals between branching, but zigzag in their entire length, and very gradually tapering from the base.toward the tips, which are blunt and rounded or compressed and bifurcate; alive for a variable distance, and sometimes for nearly their entire length, but generally dead and overgrown with nullipores and sponges below. Terminal branchlets may be $70^{\mathrm{mm}}$ long without dividing. Cells from 1.5 to $2.5^{\mathrm{mm}}$ in diameter, varying from shallow to very deep, generally subcireular and regular in outline, oceasionally somewhat crowded. The color of living specimens, according to Dr. Palmer, is violet and purplish.

Rodriguez Creek, about 40 miles south of Cape Florida (Pl. XVI, fig. 3).From this locality we have many specimens, somewhat similar in growth to those from Stock Island, the branches of about the same diameter 
but dividing more rapidly and forming denser clumps, not unlike some of the more open ones of furcata, excepting for the larger size of the branches. Branching occurs at intervals of about 10 to $30^{\mathrm{mm}}$, but is often less frequent and the angle of divergence is generally less than in the Stock Island specimens, due to the more numerous and closer branches. In some specimens the tips of nearly all the terminal branchlets are more or less enlarged and fureate or digitate as in furcata. The largest specimen measures $20^{\mathrm{cm}}$ in height and $25^{\mathrm{cm}}$ in width. The cells are generally circular and may reach a diameter of $2.5^{\mathrm{mm}}$. Depth of water 1 foot at low tide. A single specimen from the Tortugas cannot be distinguished from this variety.

Dry Tortugas.-A large series of specimens from the Tortugas exhibits a very wide range of variation, tending in one direction towards the Bermuda specimens described below. The clumps are generally dense, sometimes very close in texture, the lower branches often much enlarged and the basal portion frequently nearly solid. Branches divergent or more or less parallel and vertical, dividing either rapidly or distantly, occasionally coalescing, and thus forming clumps that vary greatly in character and proportions ; sometimes low, convex, or hemispherical, at others tall, enlarging upward. One tall clump consisting of stont, ascending, closely-placed branches measures about $30^{\mathrm{em}}$, both in height and spread (Plate XVIII, fig 2). Some of the specimens resemble those from Rodriguez Creek both in the mode of branching and in the character of the tips of the terminal branchlets, but such clumps are generally lower and denser at the Tortugas. The main branches range in diameter from 15 to $25^{\mathrm{mm}}$. Terminal branchlets large and rounded at the tips, or more or less compressed, broadened and bifurcate, or trifurcate, sometimes rapidly tapering. The cells vary greatly in size and character, and may be eircular or much crowded and polygonal ; the walls are rarely very thick. One specimen, measuring $13^{\mathrm{cm}}$ in width and $4^{\mathrm{em}}$ in height, consists of a small solid base from which arise seven very stout, rapidly tapering, irregular, and more or less sinuose and divergent trunks, separated below by very narrow interspaces. On the upper side these trunks give off from two to six short, stout, rounded, simple branches or lobes, from 12 to $24^{\mathrm{mm}}$ in length.

Eastern Dry Rocks, 9 miles southwest of Key West (Pl. XIX, fig. 1).The most exceptional forms in the collection are from this locality. They are apparently stunted growths and form very dense convex clumps, consisting of short, stout, very irregular, generally closely placed branches, arising from a more or less solid base. The branches all reach to about the same height, enlarge upward, and toward the summits are usually much divided, forming broad lobes, short, stout, simple branchlets or mammillations. The largest clump measures $20^{\mathrm{cm}}$ in diameter and $12^{\mathrm{cm}}$ in height; the terminal lobes may have a spread of $20^{\mathrm{mm}}$. The cells in all cases are deeply excavated, crow ded, and with thin walls; they vary in size, but measure on an average about $1 . \tilde{5}^{\mathrm{mm}}$ 
in diameter. The branches are alive for 10 to $40^{\mathrm{mm}}$ only. Color of living specimens yellow. A similar specimen in the old collection is labeled Tortugas.

Bermuda.-From this region, which is represented by a number of specimens, we recognize two general forms of growth, connected by intermediate varieties. Une is said to be from more shallow water than the other and has a stunted appearance, probably due to its being more or less exposed or brought close to the surface during spring tides. The deeper water variety (Pl. XVIII, fig. 1) consists of moderately stout, numerous, ramifying, sometimes coalescing branches, dividing at very unequal intervals, more or less sinuose, and forming rather dense clumps, more dense than the similar growths from the Tortugas, of which there are several in the collection. The lower branches are often much thickened, but not consolidated. The upper branches are usually about 10 to $20^{\mathrm{mm}}$ thick, circular or more or less compressed, proliferous, the branchlets divergent, blunt, and rounded at the tips or enlarged and fureate.

The shallow-water variety (Pl.XVII, fig. 2) forms very irregular clumps and masses, which are generally nearly or quite solid below and sometimes much filled in above. These clumps may be low and spreading or of moderate height, the largest one in the collection measuring: $18^{\mathrm{cm}}$ in width and $11^{\mathrm{cm}}$ in height. The branching is similar to that described above as oceurring in the specimens from Eastern Dry Rocks, Florida, and in the single specimen with solid base from the Tortugas, but exhibits greater variation and is difficult to define. The most depressed specimen is slightly convex above and consists of very irregular, more or less flattened, rather broad, lobed, and digitate-branches or processes, spreading laterally and to a slight extent vertically, and coalescing so as to leave comparatively few irregular openings. Most of the other specimens have a much greater tendeney toward vertical growth and are composed of comparatively few, ascending, generally divergent, moderately proliferous brauches, arising from a more or less solid base, very stout below, and tapering rapidly or gradually. The branches often assume very peculiar shapes, and are usually somewhat bent or twisted; starting close together at the base, they may be widely separated or nearly contiguous above; sometimes simple throughout, at others dividing once or twice, stout and rounded at the tips or enlarged and bifurcate. They may measure $30^{\mathrm{mm}}$ or more in diameter at the base, and vary in length generally from 35 to $50^{\mathrm{mm}}$. The cells in both varieties are usually shallow, never very deep, 1 to $2^{\mathrm{mm}}$ in diameter, subcircular in places, in others more or less crowded and angular.

Nassau, New Providence.-The steamer Albatross brought from Nassau, in 1886, a few small imperfect specimens which apparently represent both clavaria and furcata. The stouter forms referred doubtfully to clavaria are branched to a very limited extent and provided with 
small crowded cells, but they have the general habit of that species. Two specimens have the characteristic shape and cells of furcata.

\section{Porites compressa Dana,}

Zoophytes, p. 553, pl. 53, fig. 5, 8, 1846.-Quelch, Challenger Reef-Corals, p. $180,1886$.

Sandwich Islands; U. S. Expl. Exped., 18:38-42, types (651, 653, 711).

5. Porites cribripora Dana, (?)

Zoophytes, p. 564, pl. 55, fig. 5, 1846.

The collection contains a single specimen which appears to be one of Dana's types of this species, thongh it is not the specimen figured by him. It bears the catalogue number 670 , which would indicate that it belonged to the collection received from the U.S. Exploring Expedi. tion, but it has no other label, and no name or locality was entered under this number in the original record book in which the collection was catalogued. It also corresponds to some extent with Porites explanata Quelch, *obtained by the Challenger Expedition at the Philippines. Dana's specimens were from the Fiji Islands.

6. Porites cylindrica Dana,

Zoophytes, p. 559, pl. 54, fig. 4, 1846.

Fiji Islands (?); U. S. Expl. Exped., 1838-'42, type (708).

7. Porites favosa Dana,

Zoophytes, p. 564, pl. 55, fig. 4, 1846.

Fiji Islands ; U. S. Expl. Exped., 1838-42, type (672).

8. Porites fragosa Dana,

Zoophytes, p. 563, pl. 55, fig. 9, 1846.

Fiji Islands ; U. S. Expl. Exped., 1838-42, type (643).

9. Porites furcata Lamarck.

Porites furcata Lamarck, Hist. des Anim. sans Vert., ii, p. 271, 1816.-Dana, Zoophytes, p. 555, 1846.-Agassiz, Mem. Mus. Comp. Zool., vii, No. 1, pl. xii, fig. 7, pl. xvi, figs. 13-20.

Porites recta Lesueur, Mem. du Mus., vi, p. 288, pl. 17, fig. 16, 1820.-Dana, Zoophytes, p. 556, 1846.

(?) Porites flexuosa Dana, Zoophytes, p. 554, 1846.

(Plate XV ; pl. XVII, fig. 1.)

Bahamas: Nassau, New Providence; U. S. Fish Comm. str. Albatross, 1886 (15869).

Florida: (3086).

Cape Florida: E. Palmer, 1884 (15853).

(?) Cæsar's Creek, 17 miles south of Cape Florida ; E. Palmer, 1884 (15872).

Key West; H. Hemphill, 1885 (8903).

Salt Pond Key and Stock Island, about 6 miles NE. of Key West; E. Palmer, $1884(15855-15857)$.

Middle Ground, one-half mile NW. of Key West; E. Palmer, 1884 (15854).

Tortugas; Capt. D. P. Woodbury, U. S. A. (1639); Colonel Farquhar, U. S. A. (3930) ; E. Palmer, 1834 (15850-15852).

Barbados, West Indies; J. D. Dana (704).

(?) Curaçao, Caribbean Sea ; U. S. Fish Comm. str. Albatross, 1884 (15858).

* Challenger Reef-Corals, p. 181, pl.11, fig. 3, 1836. 
This species consists of small, irregular, rapidly dividing branches, forming more or less dense clumps, generally of small size, but attaining a spread of at least $28^{\mathrm{em}}$ and a height of at least $18^{\mathrm{em}}$. When most perfect these clumps often have a comparatively regular, strongly convex or hemispherical shape, with the branchlets much erowded or more or less widely separated at the surface; but the majority of specimens are unsymmetrical in form. The branches and branchlets are cylindrical or more or less compressed, and generally very irregular in shape and in the extent to which they subdivide; they usually ramify in all directions, but sometimes the tendency is toward vertical growth mainly. The clumps generally start from a single stem below, and in the lower part are more or less open, but in occasional specimens the basal portion becomes nearly solid or may even be incrusting. Such specimens prob. ably grew at the surface of the water and generally have very short, stout and irregular branches. Although the branches in any form rarely exceed 12 or $13^{\mathrm{mm}}$ in diameter, the basal stem is sometimes much larger, and in one instance measures $40^{\mathrm{mm}}$. The ends of the branchlets at the surface of the clumps are often much enlarged (while in process of division) and very irregularly furcate or lobed, with sometimes as many as a dozen short protuberances. The branches very rarely coalesce either in this species or in clavaria. Nearly all the specimens from any one locality have much the same general appearance.

The Dry Tortugas (Pl. XV, figs. 1 and 2).-Most of the specimens in the collection came from two localities, viz., the Tortugas and Key West. The Tortugas series contains one hundred and twenty specimens, including the largest and finest obtained. They are, as a rule, more symmetrical than the specimens from Key West, generally with rather stouter and more regular branches, which measure from 6 to $13^{\mathrm{mm}}$ in diameter. The branching is much less rapid below than above, but toward the top it is very frequent, forming at each point of division from two to six branch. lets, some of which generally divide very soon again. These branchlets may diverge irregularly in several directions or tend to grow in a single plane, giving rise to a wide fan-shaped figure, the basal portion of which is very broad and flattened. From the frequency of branching toward the top, the ends of most of the terminal branchlets are more or less enlarged or furcate, producing the generally denser structure at the surface. The character of the growth is more or less determined by the nature of the surroundings, and while most specimens attain at least a moderate height, some, probably growing at the surface, are very low, spreading mainly from the margins. The branches and branchlets vary in shape from eylindrical to much compressed and are more or less bent and twisted. Where not killed by the filling in of sand or the growth of nullipores and other incrusting forms, even large specimens may be alive for nearly their entire height; in one case the height of the living portion is $18^{\mathrm{em}}$. The cells range in size from 1 to $2^{\mathrm{mm}}$, are usually moderately excavated and not as irregular as in the Key West specimens. 
"Growing in bunches in about 2 feet of water, forming wide belts among sponges and grass; dark yellow in color." (E. Palmer.)

Key West.-The Key West specimens differ from the above mainly in having less regular branches, forming more open clumps which have seldom the same neat appearance. The structure is less firm, the cells more irregular and crowded, and measure from 1 to $1.75^{\mathrm{mm}}$ across. Branching takes place at intervals of 5 to $20^{\mathrm{mm}}$.

Cape Florida.-A number of specimens from near Cape Florida correspond with those from the Tortugas in the mode of branching and character of the cells, but they are mostly overgrown with nullipores and sponges which have prevented a thick growth in most cases, the clumps being very irregular and the branches alive only toward the ends. One dense clump starts below from a single stem and attains a height of $13^{\mathrm{cm}}$, being inverted conical in shape. There are about six branchings within that height, and the branches and branchlets are mostly directed upwards and closely placed, but are very irregular. "Very abundant, their yellow heads just protruding from the seaweeds, grass, \&c., on a bar a little southwest of the old light-house tower of Cape Florida." (Palmer.)

Stock Island, near Key West (Pl. XV, fig. 3).-From the neighborhood of Stock Island, about 6 miles northeast of Key West, there are many specimens which may be regarded as transitional between furcata and the more slender ramose forms of clavaria, both in mode of growth and in the character of the cells. The writer is very uncertain as to their position, and they may be only extreme forms of the variety of clavaria occurring in this region, which is described above. Starting generally from a single stem, each specimen divides irregularly at more or less distant intervals, the branches divergent and often growing in nearly the same plane, forming open clumps or consisting of but few widely separated branches. The branches have about the same shape as in the common form of furcata, but are generally more regular and somewhat stouter, measuring on an average from 10 to $13^{\mathrm{mm}}$ in diameter. The cells measure from 1.5 to $2.5^{\mathrm{mm}}$, are usually more regular and less crowded than in the Key West and Tortugas forms, often subcircular in outline, and generally shallow. The specimens were collected at several places near together and each lot exhibits certain peculiarities, some tending in the direction of clavaria and others towards furcata. According to Dr. E. Palmer, one lot was from "g rassy" bottom in 2 feet of water, the specimens being yellow in color; while another was found growing on a smooth base in 7 to 9 feet of water, the specimens violet in color.

Casar's Creek, 17 miles south of Cape Florida (Pl. XVII, fig. 1).-Specimens from this locality resemble the above in mode of branching and in the size of the branches, but they form larger and denser clumps, the relations of which are even more doubtful than those from Stock Island. In their general habit they certainly approach nearer the 
typical furcata than the typical clavaria, but if we examine the cells alone, we find that they agree perfectly in their structure and general appearance with those of undoubted specimens of clavaria. The cells are large, moderately deep, comparatively solid, columella generally well developed, separated by very thick walls; the excavated portions regular, cireular, and presenting a very neat appearance.

Barbados.-Two specimens in the old collection received from Professor Dana (Cat. No. 704) were labeled "Porites recta Lesueur, Barbados." These same specimens have since been relabeled by Professor Verrill Porites furcata, var. A mistake was evidently made in writing the original label, as Dana had no specimens of recta while preparing his report on Zoophytes, having copied Lesueur's description of that species. One of these specimens is undoubtedly his flexuosa, the other his furcata, as they agree perfectly with his descriptions of the same. The relations of the specimen called flexusa are doubtful; the branches. and cells are large for furcata, but the mode of branching and the structure of the cells would permit of its being placed in that species. The cells are shallow, with the columella almost always more or less developed.

Curaçao, Caribbean Sea.-A very perfect specimen from the island of Curaçao, obtained by the Fish Commission steamer Albatross, in 1884, has been referred doubtfully to this species, as it has points in common with clavaria. It is a dense clump, arising from a single main stem, inverted eonical in shape, about $22^{\mathrm{cm}}$ high and $30^{\mathrm{cm}}$ wide on top. The branches are stout, from 10 to $17^{\mathrm{mm}}$ in diameter, the texture rather firmer than in furcata generally, the cells somewhat larger, shallow, and comparatively regular. In general appearance it is not unlike some of the more slender branched specimens of clavaria from the Tortugas.

\section{Porites lichen Dana,}

Zoophytes, p. 566, pl. 56, fig. 2, 1846.-Quelch, Challenger Reef-Corals, p. $181,1886$.

Fiji Islands; U. S. Expl. Exped., 1838-'42, type (666).

The Challenger collected this species at Honolulu.

11. Porites limosa Dana,

Zoophytes, p. 563, pl. 55, fig. 2, 1846.

Fiji Islands; U. S. Expl. Exped., 1838-'42, type (673).

12. Porites lobata Dana,

Zoophytes, p. 562, pl. 55, fig. 1, 1846.

Sandwich Islands; U. S. Expl. Exped., 1833-42, types $(646,652)$.

13. Porites lutea M.-Edwards and Haime,

Coralliaires, iii, p. 180, 1860.-Porites conglomerata Dana (non Lam.) Zoophytes, p. 561, pl. 55, fig. 3, 1846. (Teste Verrill.)

Fiji Islands ; U. S. Expl. Exped., 183ð-'42, type (683).

14. Porites mordax Dana,

Zoophytes, p. 552, pl. 53, figs. 3, 4, 1846.

Sandwich Islands; U. S. Expl. Exped., 1838-42, type (710); var. elongata Dana (707). 
15. Porites mucronata Dana.

Porites nigrescens, var. mucronata, Dana, Zoophytes, p. 558, pl. 54, fig. 2, 1846.

Porites mucronata, M.-Edwards, Cor., iii, p. 177, 1860.

Sooloo Sea ; U. S. Expl. Exped., 1838-'42, types (650, 689).

16. Porites nigrescens Dana,

Zoophytes, p. 557, pl. 54, fig. 1, 1846.

Fiji Islands; U. S. Expl. Exped., 1838-42, types (690,691).

17. Porites palmata Dana,

Zoophytes, p. 558, pl.54, fig. 3, 1846.-Quelch, Challenger Reef-Corals, p. 180, 1886.

Sooloo Sea ; U. S. Expl. Exped., 1838-'42, type (689).

18. Porites panamensis Verrill,

Proc. Boston Soc. Nat. Hist., x, p. 329, 1866; Trans. Conn. Acad. Arts and Sci., i, part 2, p. 505, 1870 .

Panama ; Sternberg (3972).

The single specimen referred by the writer to this species agrees with the description of Professor Verrill, excepting that the cells are somewhat larger, varying from 1 to $1.5^{\mathrm{mm}}$ in diameter.

19. Porites Plumieri Duchassaing et Michelotti,

Suppl. au Mem. sur les Corall. des Antilles, p. 190, pl. x, fig. 14, 1866.

St. Thomas, West Indies; U. S. Fish Comm. str. Albatross, 1884 (15873).

A single specimen obtained by the steamer Albatross agrees in all particulars with the description and figures of Duchassaing and Michelotti, excepting that the branches do not anastomose. It is probably only a variety of Porites furcata.

20. Porites porosa Verrill, (?)

Trans. Coun. Acad. Arts and Sci., i, part 2, p. 504, 1870.

La Paz, Lower California; L. Belding, 1882 (5407, 5408).

21. Porites reticulosa Dana,

Zoophytes, p. 567, pl. 56, fig. 3, 1846.

Fiji Islands; U. S. Expl. Exped., 1838-42, types (662, 663).

22. Porites solida Verrill,

Trans. Conn. Acad. Arts and Sci., i, part 2, p. 358, 1868.

Pernambuco, Brazil ; C. F. Hartt, 1875 (5362, 5365, 10963, 15516).

This species is distributed along the Brazilian coast, from Parahyba do Norte to the Abrolhos Islands, and in some places is very abundant, as near the city of Pernambuco and on the Abrolhos Reefs. It appears to be entirely wanting in the Bay of Bahia, which is rather rich in coral growths. The specimens are generally massive, sometimes incrusting.

23. Porites tenuis Verrill,

Proc. Essex Inst., v, p. 25, 1866.-Quelch, Challenger Reef-Corals, p. 184, 1886.

Loo Choo Islands (?); William Stimpson, N. Pacific Expl. Exped., type (407).

Collected by the "Challenger" at the New Hebrides and Honolulu. 


\section{Genus SYNARAA Verrill.}

1. Synaræa Danæ Verrill.

Porites contigua Dana, Zoophytes, p. 560, pl. 54, fig. 6, 1846 (non Madrepora contigua Esper).

Porites Dana M. -Edwards and Haime, Monogr. des Porit, p. 32.

Synaraa Dane Verrill, Bull. Mus. Comp. Zool., Cambridge, i, p. 43,1864.

Fiji Islands; U. S. Expl. Exped., 1838-'42, type (684).

2. Synaræa erosa Verrill.

Porites erosa Dana, Zoophytes, p. 565, pl.55, fig. 8, 1846.

Synaraa erosa Verrill, Bull. Mus. Comp. Zool., Cambridge, i, p. 42, 1864.

Sooloo Sea ; U. S. Expl. Exped., 1838-42, type (668).

3. Synaræa monticulosa Verrill.

Porites monticulosa Dana, Zoophytes, p. 566, pl. 55, fig. 7, 1846.

Synaraa monticulosa Verrill, Bull. Mus. Comp. Zool., Cambridge, i, p. 42, 1864.

Fiji Islands ; U. S. Expl. Exped., 1838-'42, type (664). 


\section{$2 \mathrm{BHL}$ Biodiversity Heritage Library}

Rathbun, Richard. 1887. "Annotated catalogue of the species of Porites and Synaraea in the UnitedStates National Museum, with a description of a new species of Porites." Proceedings of the United States National Museum 10(635), 354-366. https://doi.org/10.5479/si.00963801.10-635.354.

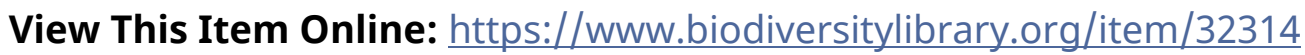

DOI: https://doi.org/10.5479/si.00963801.10-635.354

Permalink: https://www.biodiversitylibrary.org/partpdf/23731

\section{Holding Institution}

Smithsonian Libraries

\section{Sponsored by}

Smithsonian

\section{Copyright \& Reuse}

Copyright Status: NOT_IN_COPYRIGHT

This document was created from content at the Biodiversity Heritage Library, the world's largest open access digital library for biodiversity literature and archives. Visit BHL at https://www.biodiversitylibrary.org. 